\title{
Management Disclosures on Internal Control in Annual Reports- A Study on Banking Sector: Bangladesh Perspective
}

\author{
Anup Kumar Saha (Corresponding Author) \\ Lecturer, Department of Accounting and Information Systems \\ Jagannath University, Dhaka, Bangladesh \\ Web address: http://www.anupsaha.co.cc \\ E-mail: opusaha@gmail.com
}

S.M. Arifuzzaman

Assistant Professor, Faculty of Business Administration

American International University-Bangladesh (AIUB), Bangladesh

E-mail: arif_zaman48@yahoo.com

Received: March 9, 2011

Accepted: April 19, 2011

doi:10.5539/ijef.v3n5p216

\begin{abstract}
Even though no regulations require, public limited companies include management reports regarding internal controls in annual reports. Accountants and auditors are in a good position to suggest what degree of reporting is appropriate as they are directly involved in auditing financial statements and reviewing internal controls. This is a unique opportunity for management to discuss issues and concerns not communicated elsewhere in the annual report. From the very beginning there is a growing consensus as to what the content should include: financial statement presentation; purpose, nature and components of internal controls; roles of internal audit, independent auditor and audit committee. A significant number of companies studied acknowledge that "the systems are designed to provide only a reasonable assurance of meeting stated objectives." If independent auditor's attestation of such management reports were required; such a mandate would have a significant impact on roles of both the independent auditor and management.
\end{abstract}

Keywords: Internal Control (IC), Securities and Exchange Commission (SEC), Dhaka Stock Exchange (DSE), Audit Committee, 10-K.

\section{Introduction}

Public companies increasingly include management reports on internal controls in their annual reports as a good corporate governance practice. Nowadays, management is much concerned of contents what it should include in these reports.

Management reports typically discuss the following topics:

Financial statement presentation.

The purpose, nature and components of the company's internal controls.

The role of internal audit.

The role of the audit committee.

The role of the independent auditor.

Although neither the SEC nor the Company Law-1994 require them, these reports have existed for more than a decade; the debate on the mandatory inclusion of report on internal control has been a big issue for a long time. There are, of course, varying opinions as to whether the needs of financial statement users are being met by existing reporting requirements. Whether management should issue a report on internal controls and whether it w $\backslash$ should be attested by the independent are matters of further investigations.

Since accountants and auditors are the professionals directly involved in auditing financial statements and reviewing internal controls, they may be in the best position to suggest what degree of reporting is appropriate. The aim is to ensure the disclosure of information on internal control for the stakeholders and other interested groups. 


\section{Statement of the Problem}

Effective internal control is very necessary for proper identification, summarization, processing and communication of information to the stakeholders of the company. Management needs to provide all necessary material information to the stakeholders i.e users of the annual statement. As part of it internal control details should be disseminated to the stakeholders to facilitate in their decision making process. Whether or not these information are actually provided for the stated purpose and the extent and adequacy of such disclosures has been surveyed and analyzed in this study.

\section{Objectives of the Paper}

The main objective of the study is to find out the extent of internal control disclosure for the convenience of the users of the annual reports. The extent of the disclosure would lead us to study of several other aspects as well. These are as follows-

The effectiveness and efficiency of the internal control

The contents on IC in the management report

The purpose and nature of IC

The internal auditors' role

The audit committee's role

The external auditor's role

This study aims at finding the extent of disclosures in management reports in the above areas.

\section{Literature Review}

This is more or less a maiden area in the perspective of Bangladesh. Though several papers have been published internationally, no significant study on internal control disclosure has taken place in Bangladesh.

According to a global survey released in $2000,69 \%$ of investment professionals said the overall quality of financial information disclosed by most publicly traded companies had improved. Nearly $75 \%$ respondents pointed to executive interviews as key sources of information, followed by annual reports and financial news releases.

Insert graphical figure 1 here

According to findings of Accounting Trends and Techniques (1999), approximately 58\% of public companies included management reports in their $10-\mathrm{K}$. This is the one place in an annual report where management can focus readers' attention on issues not systematically discussed elsewhere. A content analysis can help both the writers and users of the reports, as well as the outside auditors, in determining what specific items warrant inclusion.

While the focus in general is on the effectiveness of internal controls, the specific components of internal control are by no means consistent across companies. The differences noted in the reports may reflect the variations in how companies structure their internal control systems or they may reflect the differences in the companies' reporting philosophies. So the content of such reports varies considerably.

An analysis of the annual reports of the 1998 Fortune 100 revealed 78 companies had included management reports, virtually all of which began with a statement that management took responsibility for the presentation of the reports in this study of the financial statements. Ninety-seven percent said the financial statements conformed to GAAP and $15 \%$ said the financial statements represented fairly the company's financial position and results of operations.

\section{Justification of the Study}

An annual report is a comprehensive report on a company's activities throughout the preceding year. Annual reports are intended to give shareholders and other interested people information about the company's activities and the financial performances. (Downes and Barrons, 1995).

Investors and other external stakeholders had a limited interest in the internal control of the company as the idea was they are to know only the results not how the results are arrived at. But internal control is an effective way to find out further insight into the financial results in which stakeholders are interested in. From a disclosure and review on IC, it would be further understandable of future trends of the financial results, the reliability would be a lot higher and above all the objective of effective corporate governance, which is a hot issue nowadays for ensuring the interests of the related parties, would be well fulfilled.

\section{Methodology of the Study}

Here in this study has been analyzed the current status of information disclosure on internal control provided by the 
management in annual report. In this regard, the several management reports included in annual reports have been studied. The study was aimed at collecting and analyzing secondary data from the annual reports of some selected banks enlisted in the Dhaka Stock Exchange (DSE) on a sample basis.

At present there are 30 banks (Appendix) enlisted DSE. Out of this population, seven banks have been selected on a random basis. Here, standard size is about $24 \%$ of the total population. Annual reports of year 2009 have been taken for the study purpose. For the study purpose management reports of the sample banks were thoroughly analyzed with a view to finding out the present scenario of disclosure status on internal control pursued by the banks within the organizations. The seven banks selected for the study are AB Bank Ltd, Dutch Bangla Bank Ltd, Jamuna Bank Ltd, Mercantile Bank Ltd, Mutual Trust Bank Ltd, Premier Bank Ltd and Southeast Bank Ltd (in alphabetical order).

\section{Analysis of the Study Findings}

Contents of IC:

In our survey, we have found $100 \%$ banks include a management report in the form of report from Board of Directors. Other management reports include Chairman's report, managing director's report and so on. 14\% said financial statements are in conformity with GAAP.

All of the seven banks surveyed said that financial statements represent fairly the company's financial position and results of operations. In $71 \%$ cases, management report discusses about presentations of financial statements. Same number of banks included the purpose, nature and components of the internal control in their director's report. 57\% mentioned about the role of internal audit, $71 \%$ included the role of audit committee and $43 \%$ included the role of independent external auditor in their director's report. $86 \%$ of the banks taken as sample said the focus of internal control reports is effectiveness of the internal control. Only one out of seven have focused on safe working place in terms of perfect working condition (14\%).

Purposes and Nature of IC:

All the banks surveyed mention a system of internal control. According to it, the proposes are mentioned as followsall of them identified reliable financial reporting, $86 \%$ mentioned safeguarding of assets, $71 \%$ said the objective was encouraging adherence to management's prescribed policies and procedures, while just above a quarter- $29 \%$ linked IC with ethical conducts. Five out of seven specifically cited preventing and detecting fraudulent financial reporting as one of their purposes of IC.

Several reports identified specific components of their internal control structures. The most frequently cited were the existence of an internal audit function $(86 \%)$ and segregation of duties $(86 \%)$, followed by the maintenance of policies and procedures $(71 \%)$, the selection and training of good personnel (29\%). Also mentioned was periodic and special inspection in branches. Several of the reports noted that the policy addressed such elements as conflict of interest, compliance with applicable laws and confidentiality concerns.

\section{Limitations of IC:}

There are some inherent limitations of internal controls and these limitations are also carefully acknowledged in the respective annual reports. $29 \%$ of them pointed out that the systems' designs provided only "reasonable assurance" of meeting stated objectives. Twenty nine percent said the internal controls' cost should not exceed anticipated benefits.

In spite of these limitations addressed by them, managements often assure the users of the annual report about the soundness of their internal control. Each and every bank surveyed claims that their internal control system is strong and effective. Among those claimers, eighty six percent has mentioned the basis of such assertions.

Internal Audit's Role:

Functions of the internal audit department occupy a great deal of importance in any annual report. The most frequently cited role of such department is monitoring compliance with IC structure and assessing its effectiveness $(86 \%)$. A bit more than half of the banks surveyed noted internal audit provides recommendations to improve controls and correct deficiencies (57\%).

All most all of them say that the internal auditors are more closely lined with audit committee and board of directors. Though some of them indicated there was a great deal of independence for internal auditors as well.

\section{The Audit Committees Role:}

All the reports referred to have an audit committee. Of these, none said its members were independent or not part of management. All of them said their audit committee includes board of directors as per rule of land. $86 \%$ pointed that 
the audit committee involves one independent director. These high rates of assertions are quite understandable as those were included in the mandatory compliance report of the Securities and Exchange Commission. 57\% has stated that their independent auditors have free and full access to the audit committee and the rest have not mentioned anything regarding this matter. On the other hand $86 \%$ have said the independent directors have full and free access to the audit committee, whereas only one of the samples taken (14\%) mentioned nothing regarding this matter.

The following responsibilities of the audit committee have been stated as per director's report; the percentages in parentheses refer to the portion of the 7 companies with an audit committee.

Oversight of financial reporting process $(86 \%)$.

Review of internal controls (86\%).

Review the scope and results of internal and independent audits performed (100\%).

Oversight of the internal and independent audit functions (57\%).

Make recommendations concerning the selection of the independent auditor (86\%).

Oversight of management (57\%).

Independent Auditor's Role:

All the directors' reports mentions about the independent audit of the company, appointment of independent auditors. About $86 \%$ of them referred to the audit report included in the annual report. Audit reports mentioned about the basis of the audit work and sufficiency of information provided by the management for the audit purpose.

All the annual reports surveyed state that the independent auditors have included a consideration for the internal control for the purpose of formulating opinion on the reliability of financial statements, not for the evaluating the efficiency of internal control. Most of them used the terms review of internal control and test check of internal control (60\%), followed by terms evaluation and assessment, consideration $(40 \%)$ and only $20 \%$ each used the terms obtaining an understanding of IC, study of IC and examination of IC.

The management reports usually do not make similar distinctions. A statement in a management report that the independent auditor has "considered" "reviewed" or "examined" the company's internal controls unintentionally might cause a reader to infer that the auditor has indicated the internal control system is working effectively. In most cases, such an inference would be misleading since the auditor was not engaged to express an opinion on the adequacy of the controls. Unless specifically engaged to assess or evaluate a company's internal control system, independent auditors examine internal controls only for the purpose of designing their overall audit tests of the financial records. Beyond that, no testing of internal controls is required. For this reason the language that is used may merit closer scrutiny.

Since management reports are typically included in companies' annual reports, which contain audited financial statements, the auditor is required to read them. "In reading such information, the auditor should evaluate specific references by management that deal with the auditor's consideration of internal controls in planning and performing the audit of the financial statements, particularly if such reference would lead the reader to assume that the auditor had performed more work than required under generally accepted accounting standards or would lead the reader to believe the auditor was giving assurances on internal control" (from AICPA, Professional Standards, AU section 9550.14, Other Information in Documents Containing Audited Financial Statements: Auditing Interpretations of Section 550 ).

The findings of this study indicated that the word most commonly used to describe the nature of the auditor's consideration of the company's internal controls was "reviewed." Because "a statement by management that the auditors had 'reviewed' the company's internal controls would be inappropriate," (see footnote to AU section 9550.14), auditors may need to more closely scrutinize clients' management reports to comply with the standard's guidance.

\section{Conclusion and Suggestion for Further Research}

Management reports in banking sector include disclosures on internal control as a voluntary initiative. The level of disclosure varies with different companies. Methods and presentations of such information also have varying forms. The main problem involved here is the lack of standardized format from a regulatory body. There is no standard reporting framework. Even then, in this study, findings suggest that the disclosure is at a quite satisfactory level in our banking sector as compared to the international surveys.

This study was limited to internal control disclosure of banking sector only. The sample size was about $25 \%$ of the 
population. Further researches can be done in other sectors as well. Contrast can be found out between the extent and nature of internal control disclosure in banking sectors and other sectors. Banking sector seems to have more disclosure as compared to other sectors with regard to disclosure practice in corporate social responsibility, corporate governance and other voluntary disclosures. Similar studies can be done to find out the case in internal control disclosure as well.

Another research foray can be put on the relationship between internal control disclosure extent and earnings of the company. It may happen the firm earns more profit, discloses more on internal control. The report becomes a vehicle for defining management's control strategy, for explaining how its practices compare with those of other companies, and for highlighting where its efforts may represent cutting-edge attempts to make its company more profitable and efficient. Companies with innovative programs can use these reports to emphasize how important these initiatives are. (Willis and Lightle, 2000)

Further study can be on whether management reports need an attestation by independent auditor or not. If independent attestation of those were required, such a mandate would have a significant impact on the roles of both the independent auditor and management in this process. In traditional auditing and attestation services, the profession draws a sharp line between an "audit" and a "review." Specific standards guide the practitioner in providing these differentiated services. Perhaps equally critically, the audit and review reports themselves attempt to clarify for the readers the nature and extent of the work performed. (Willis and Lightle, 2000)

\section{References}

AICPA, Professional Standards, AU section 9550.14, Other Information in Documents Containing Audited Financial Statements: Auditing Interpretations of Section 550

Ajinkya, B., Bhojraj, S., Sengupta, P. (2005). The association between outside directors, institutional investors and the properties of management earnings forecasts. Journal of Accounting Research 43(3), 343-376. doi:10.1111/j.1475-679x.2005.00174.x, http://dx.doi.org/10.1111/j.1475-679x.2005.00174.x

AshbaughSkaife, H., Collins, D., Kinney, W. (2007). The discovery and reporting of internal control deficiencies prior to SOXmandated audits. Journal of Accounting and Economics 44, 166-192. doi:10.1016/j.jacceco.2006.10.001, http://dx.doi.org/10.1016/j.jacceco.2006.10.001

AshbaughSkaife, H., Collins, D., Kinney, W., LaFond, R. (2008). Internal control deficiencies, remediation and accrual quality. The Accounting Review 83 (1), 217-250. doi:10.2308/accr.2008.83.1.217, http://dx.doi.org/10.2308/accr.2008.83.1.217

Association for Investment Management and Research, Corporate Disclosure Survey, Charlottesville, Virginia, www.aimr.org/standards

Ball.R, (2004). Corporate governance and financial reporting at Daimler-Benz (DaimlerCrysler) AG: From a "Shareholder Value" Model. In: Luez, C., Pfaff, D., Hopwood, A., (Eds.) The Economics and Politics of Accounting. London: Oxford University Press, 103-145.

Beneish, D., Billings, M., Hodder, L. (2008). Internal control weaknesses and information uncertainty. The Accounting Review 83, 665-703. doi:10.2308/accr.2008.83.3.665, http://dx.doi.org/10.2308/accr.2008.83.3.665

Birnberg, J.B., Shields, M.D. and Young, S.M. (1990). The case for multiple methods in empirical management accounting research (with an illustration of budget setting). Journal of Management Accounting Research, Fall, $33-66$.

Chan, K., Farrell, B., Lee, P. (2008). Earnings management of firms reporting material internal control weaknesses under Section 404 of the SarbanesOxley Act. Auditing, A Journal of Practice and Theory, 27 (2), 161-179.

DeFond, M., Raghunandan, K., Subramanyam, K.R. (2002). Do nonaudit service fees impair auditor independence? Evidence from going concern audit opinions. Journal of Accounting Research 40, 1247-1274. doi:10.1111/1475-679X.00088, http://dx.doi.org/10.1111/1475-679X.00088

Downes, John and Barron, (1995). Jordon E. G., Dictionary of Finance and Investment Terms. ISBN: 0812090357, pg 23

Doyle, J., Ge, W., McVay, S. (2007a). Accruals quality and internal control over financial reporting. The Accounting Review 82, 1141-1170. doi:10.2308/accr.2007.82.5.1141, http://dx.doi.org/10.2308/accr.2007.82.5.1141

Doyle, J., Ge, W., McVay, S. (2007b). Determinants of weaknesses in internal control over financial reporting. Journal of Accounting and Economics 44, 193-223. doi:10.1016/j.jacceco.2006.10.003, http://dx.doi.org/10.1016/j.jacceco.2006.10.003 
Elder, R., Zhang, Y., Zhou, J., Zhou, N. (2009). Internal control weaknesses and client risk management. Journal of Accounting, Auditing and Finance.

Ge, W., McVay, S. (2005). The disclosure of material weaknesses in internal control after the SarbanesOxley Act. Accounting Horizons 19, 137-158. doi:10.2308/acch.2005.19.3.137, http://dx.doi.org/10.2308/acch.2005.19.3.137

Ghauri, P., Gronhaug, K. and Kristianslund, L. (1995). Research methods in business studies: a practical guide. Prentice Hall.

Graham, J., Harvey, C., Rajgopal, S. (2005). The economic implications of corporate financial reporting. Journal of Accounting and Economics 40, 3-73. doi:10.1016/j.jacceco.2005.01.002, http://dx.doi.org/10.1016/j.jacceco.2005.01.002

Gupta, P.P., and Nayar, N. (2007). Information content of control deficiency disclosures under the Sarbanes-Oxley Act: An empirical investigation. International Journal of Disclosure and Governance 4, 3-23. doi:10.1057/palgrave.jdg.2050047, http://dx.doi.org/10.1057/palgrave.jdg.2050047

Hopper, T.M., Uddin, S., and Wickramasinghe, D, 2004a. Management accounting and control research in the Third World: A review of the current state. Working Paper, Manchester school of Accounting and Finance, University of Manchester.

Krishnan, J. (2005). Audit committee quality and internal control: An empirical analysis. The Accounting Review 80, 649-675. doi:10.2308/accr.2005.80.2.649, http://dx.doi.org/10.2308/accr.2005.80.2.649

Lang, M., Lundholm, R., (1996). Corporate disclosure policy and analyst behavior. The Accounting Review 71 (4), 467-492.

Larcker, D., Rusticus, T. (2008). On the use of instrumental variables in accounting research. Working paper, Stanford University.

Mei, Feng; Li, Chan and Mcvay, S. (2009). Internal Control and Managemnt Guidance, Journal of Accounting and Economics, USA.

Neimark, M. \& Tinker, A.M. (1986). The Social Construction of Management Control Systems. Accounting, Organisations \& Society, 11, 4-5: 369-395.

Ogneva, M., Subramanyam, K.R., Raghunandan, K. (2007). Internal control weakness and cost of equity: Evidence from SOX Section 404 disclosures. The Accounting Review 82 (5), 1255-1297. doi:10.2308/accr.2007.82.5.1255, http://dx.doi.org/10.2308/accr.2007.82.5.1255

Public Company Accounting Oversight Board (PCAOB). (2007). Auditing Standard No. 5-An Audit of Internal Control Over Financial Reporting That Is Integrated with an Audit of Financial Statements.

Rogers, J., Stocken, P. (2005). Credibility of management forecasts. The Accounting Review 80, 1125-1162. doi:10.2308/accr.2005.80.4.1233, http://dx.doi.org/10.2308/accr.2005.80.4.1233

Tang, A., Xu, L. (2007). Institutional ownership, internal control material weakness and firm performance. Working paper, Morgan State University.

Willis David M. and Lightle Susan S. (2000). Management Reports on Internal Controls- What do they say about your company? Journal of Accountancy, AICPA.

\section{Appendix:}


Table 1. Enlisted banks in DSE (Population):

\begin{tabular}{|l|l|}
\hline AB Bank & NCC Bank \\
\hline City Bank & Social Investment Bank \\
\hline IFIC Bank & Dutch Bangla Bank \\
\hline Islami Bank & Mutual Trust Bank \\
\hline National Bank & Standard Bank \\
\hline Pubali Bank & One Bank \\
\hline Rupali Bank & Bank Asia \\
\hline UCBL & Mercantile Bank \\
\hline Uttara Bank & EXIM Bank \\
\hline ICB Islami Bank & Jamuna Bank \\
\hline Eastern bank & Brac Bank \\
\hline Al Arafa Bank & Shahjalal Bank \\
\hline Prime Bank & Premier Bank \\
\hline Southeast Bank & Trust Bank \\
\hline Dhaka Bank & First Securities Bank \\
\hline
\end{tabular}

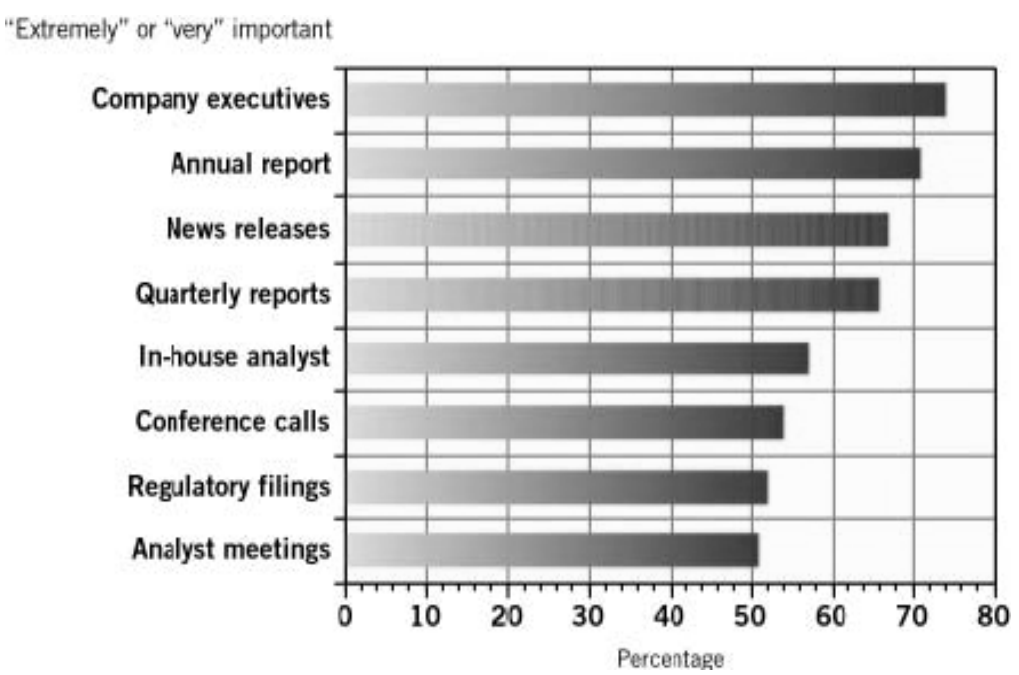

Source: Corporate Disclosure Survey, Association for Investment Management and Research, Charlottesville, Virginia, www.aimr.org/standa. rds

Figure 1. 